\title{
Learning Failures and Barriers in Schools During a Pandemic at Indonesia: A Literature Review
}

\author{
Kegagalan dan Hambatan Pembelajaran di Sekolah pada Masa Pandemi di Indonesia: \\ Suatu Studi Pustaka
}

\begin{tabular}{l}
\hline Author \\
\hline Purba Wahyu Adi \\
Universitas Sebelas Maret \\
Surakarta \\
purba.wahyuadi@student.uns.ac.id
\end{tabular}

Trisno Martono ${ }^{2}$

Universitas Sebelas Maret

Surakarta

trisnomartono@staff.uns.ac.id

\section{Sudarno $^{3}$}

Universitas Sebelas Maret

Surakarta

sudarno251168@gmail.com

\section{Duconomics}

\section{Sci-meet}

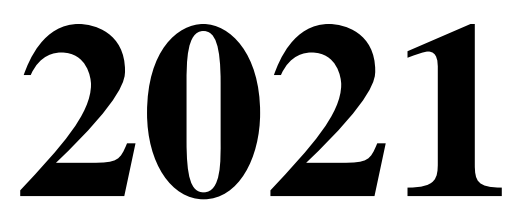

VOLUME 1

JULI

Page

\section{0-165}

\section{DOI}

10.37010/duconomics.v1.5436

Corresponding Author

purba.wahyuadi@student.uns.ac.id

(085230975597)
Abstract

The effectiveness of learning during the Covid-19 pandemic experienced obstacles and triggered the failure of the teaching and learning process in schools. Students are directly affected

and if left for a long time will experience learning loss. This

study aims to describe the obstacles that trigger failure in learning in schools during the pandemic in Indonesia through a literature review. Searching research journal data using

Google Scholar database from various available journals. Article criteria can be in the form of qualitative and quantitative approaches. There are no restrictions on the year of publication or the use of language. In this literature study, 20 articles have been screened by authors. The results of the review generally describe learning barriers during the pandemic, namely; pedagogical barriers, barriers to facilities and infrastructure, internal barriers to students, and barriers to the external environment of students.

Keywords
Failure, Barriers, Learning, Covid-19

Abstrak

Efektivitas pembelajaran pada masa pandemi Covid-19 mengalami hambatan dan memicu kegagalan proses belajar mengajar di sekolah. Peserta didik terkena dampak langsung dan jika dibiarkan secara waktu yang lama akan mengalami learning loss. Studi ini bertujuan untuk menjabarkan hambatan-hambatan yang memicu kegagalan pada pembelajaran di sekolah selama pandemi berlangsung di Indonesia melalui kajian pustaka. Pencarian data jurnal penelitian menggunakan database Google Scholar dari

berbagai jurnal-jurnal yang tersedia. Kriteria artikel dapat berupa pendekatan kualitatif dan kuantitatif. Tidak ada batasan tahun terbitan maupun penggunaan bahasa. Pada studi pustaka

ini menggunakan 20 artikel yang sudah melalui screening penulis. Hasil review pada umumnya menjabarkan hambatan pembelajaran pada masa pandemi yaitu; hambatan pedagogis, hambatan sarana dan prasarana, hambatan internal siswa, dan hambatan lingkungan eksternal siswa. 


\section{PENDAHULUAN}

Covid-19 merupakan virus yang mewabah di seluruh dunia tanpa terkecuali di Indonesia. Virus ini dengan cepat menularkan pada manusia melalui kontak langsung ataupun saluran pernafasan. Menurut data statistik dari google.com, Indonesia sampai sekarang ini memiliki 1,92M kasus yang terjangkit virus Covid-19, 1,75M jiwa dinyatakan sembuh dan 53,116 dinyatakan meninggal. Pada tanggal 14 Juni 2021 rata-rata masih terjadi kasus baru sebesar 8,074 jiwa. Hal tersebut tentunya Indonesia masih sangat rawan dan belum mampu menekan penyebaran Virus Covid-19 meskipun langkah-langkah antisipasi dari pemerintah telah dilakukan. Padahal adanya Virus Corona ini menimbulkan dampak berbagai multidimensi, baik dari perekonomian nasional maupun proses berjalannya pendidikan.

Dampak utama pandemi Covid-19 pada bidang pendidikan yakni proses belajar mengajar tidak dapat dilakukan secara tatap muka (luring) karena pemerintah melalui kementerian pendidikan memfokuskan kesehatan dan keselamatan warga. Sebagaimana yang tertulis dalam surat edaran Kemendikbud (2020) dalam rangka mencegah penyebaran Virus Corona, mahasiswa, guru, dosen, dan siswa diharapkan mengikuti protokol kesehatan serta mengganti proses belajar mengajar secara daring dari rumah. Proses pembelajaran tetap harus berlangsung meskipun dilakukan secara daring dengan harapan berjalan efektif seperti pembelajaran tatap muka langsung.

Namun faktanya, proses belajar mengajar pada masa pandemi mengalami banyak hambatan seperti: infrastruktur yang kurang memadai (Rahayu, Amalia, \& Maula, 2020) (Afnibar, Fajhriani, \& Putra, 2020) (Ramdhani \& Wulandari, 2021) (Lubis, 2020), kurang efektifnya metode pembelajaran yang dipakai (Agustin, Puspita, Nurinten, \& Nafiqoh, 2020) (Kahfi, 2020), kurangnya dukungan keluarga (Kafi, Mahmudah, \& Muslimah, 2020) (Wahyuningsih, 2021), motivasi belajar siswa yang menurun (Bahar, 2020) (Yudhistira \& Murdiani, 2020). Kendala tersebut mengakibatkan pembelajaran masih jauh dari kata efektif bahkan sebagian besar sekolah mengalami kegagalan pembelajaran pada masa pandemi (Nurkolis \& Muhdi, 2020). Kegagalan pembelajaran ini apabila terus dibiarkan dalam jangka waktu yang lama akan mengakibatkan loss learning dan siswa rentan putus sekolah karena sudah tidak memiliki motivasi belajar.

Dari berbagai permasalahan tersebut perlu dikaji secara mendalam tentang hambatan/kendala yang sering dihadapi oleh sekolah-sekolah di Indonesia agar kedepannya dapat menentukan sikap kebijakan yang sesuai baik dari pemerintah, sekolah, guru, orang tua maupun siswa agar pembelajaran menjadi lebih efektif. Pemecahan masalah pembelajaran pada masa pandemi harus dilihat secara menyeluruh mulai dari tingkat pendidikan dini sampai tingkat perguruan tinggi agar mendapatkan gambaran secara rinci.

Berdasarkan artikel-artikel penelitian yang telah dikaji mengenai kegagalan dan hambatan pembelajaran di sekolah pada masa pandemi, peneliti merasa penting untuk melakukan kajian pustaka terhadap hambatan pembelajaran yang terjadi di Indonesia. Kajian ini merujuk pada temuan hasil penelitian yang relevan dan yang telah diterbitkan pada jurnal ilmiah. Tujuan utama penulisan artikel ini yaitu untuk mendeskripsikan hasil temuan terbitan dari jurnal-jurnal ilmiah mengenai hambatan pembelajaran yang terjadi baik dari sekolah tingkat dasar sampai perguruan tinggi. Artikel ini diharapkan mampu menjadi rujukan serta bahan pertimbangan pemangku kebijakan untuk melakukan pembenahan agar pada kondisi pandemi pembelajaran tetap dapat dilaksanakan secara efektif.

\section{METODE}


Metode yang digunakan pada penelitian ini yakni analisis literature review berdasarkan atikel-artikel ilmiah yang relevan dengan topik permasalahan. Sumber artikel menggunakan database dari Google Scholar dengan menerapkan kata kunci "hambatan', "pembelajaran", "covid-19"."kendala","efektivitas". Strategi penentuan artikel dipilih berdasarkan screening penulis melalui: (1) terbitan dari jurnal bereputasi, (2) ruang lingkup topik terjadi di wilayah Indonesia, (3) tidak ada batasan tingkat pendidikan (4) tidak ada batasan penggunaan bahasa, dan (5) tidak ada batasan penggunaan metode penelitian.

Prosedur analisis melalui beberapa tahapan. Pertama, mengkategorikan berbagai hambatan yang terjadi pada berbagai tingkat pendidikan. Kedua, menganalisis hasil temuan dari artikel untuk melihat signifikansi dan diferensiasi hambatan pembelajaran. Ketiga, menyimpulkan hasil temuan dari artikel yang telah dianalisis untuk menjawab permasalahan penelitian.

\section{HASIL DAN PEMBAHASAN}

\section{Hasil}

Berdasarkan strategi penelitian yang digunakan, maka diperoleh 20 artikel ilmiah dari berbagai publikasi jurnal dengan topik permasalahan yang relevan. Berikut merupakan temuan penelitian. Pertama, karakteristik artikel publikasi merupakan terbitan tahun 2020 sebanyak 13 $\operatorname{artikel}(65 \%, \mathrm{n}=13)$. Kebanyakan artikel menggunakan metode kualitatif $(\mathrm{n}=11)$ dan sisanya $(\mathrm{n}=2)$ menggunakan metode kuantitatif. Sedangkan pada terbitan tahun 2021 hanya terdapat 7 artikel $(35 \%, n=7)$ dengan tetap didominasi oleh penelitian kualitatif $(n=5)$ dan sisanya kuantitatif $(\mathrm{n}=2)$.

Keseluruhan artikel merepresentasikan hasil temuan tentang hambatan pembelajaran di masa pandemi dengan subjek penelitian meliputi jenjang Taman Kanak-kanak (TK) $(n=1)$, tingkat sekolah dasar (SD) $(n=6)$, Sekolah Menengah Pertama $(n=1)$, Sekolah Menengah Atas (SMA) $(n=4)$, dan perguruan tinggi ( $n=7)$. Meskipun artikel memuat dari berbagai jenjang pendidikan, akan tetapi terdapat permasalahan pembelajaran yang sama, yakni: (1) kurang tersedianya sarana dan prasana yang memadai, (2) kurangnya kemampuan guru/dosen untuk berinovasi terhadap metode pengajaran, (3) kurangnya pemahaman pembelajaran melalui media elektronik, (4) kurangnya dukungan ekonomi siswa, (5) kurangnya dukungan orang tua (6) kurangnya akses koneksi internet yang stabil, dan (7) kurangnya motivasi belajar peserta didik.

Berdasarkan 20 artikel yang telah dianalisis, hanya terdapat 1 artikel yang mengatakan bahwa pembelajaran selama pandemi dapat dilakukan secara efektif, hampir semuanya $(\mathrm{n}=$ 19) meyatakan bahwa pembelajaran selama masa pandemi belum dapat dikatakan efektif. Temuan ini menunjukkan bahwa ada peluang supaya pembelajaran pada masa pandemi tetap berjalan secara efektif.

\section{Pembahasan}

Pembelajaran pada masa pandemi tentunya merupakan tantangan baru bagi semua pihak, pemerintah, sekolah, guru, siswa, dan orang tua. Kondisi ini mengharuskan semua elemen pendidikan bekerja dan melaksanakan pembelajaran melalui daring dari rumah. Tantangan e-learning di era pandemi membutuhkan penyesuaian dengan cepat karena diperkirakan ancaman Virus Covid-19 akan berlangsung lama. Metode pembelajaran yang inovatif diperlukan serta dukungan dari semua pihak agar pembelajaran tetap berjalan secara efektif. 
Berdasarkan analisis temuan artikel, sebenarnya ada kemungkinan pembelajaran dapat dilaksanakan secara efektif. Sebagaimana pendapat Ramdhani \& Wulandari (2021) pembelajaran dapat berjalan efektif pada mata kuliah kesekretariatan dengan melihat indikator hasil belajar, aktivitas mahasiswa, dan respon mahasiswa tergolong baik. Keberhasilan pelaksanaan e-learning pada kasus ini dikarenakan adanya minat dan motivasi mahasiswa untuk terus belajar serta daya dukung lingkungan yang bagus. Namun juga ditemukan kendala kecil seperti koneksi internet yang terputus, kelas yang kurang kondusif, dan menambah kegugupan ketika praktikum. Pembelajaran daring berpengaruh signifikan dan positif terhadap hasil belajar (Yupelmi, 2020).

Pada 19 artikel lainnya, menyatakan bahwa pembelajaran pada masa pandemi belum efektif. Hal ini dapat dilihat dari banyaknya hambatan yang dialami oleh guru, orang tua, dan siswa. Ketidaksiapan menghadapi pembelajaran berbasis e-learning faktor utamanya yakni karena belum terbiasa melaksanakan pembelajaran daring. Berdarakan kajian literature maka dapat dirangkum ke dalam 4 hambatan pembelajaran berbasis daring di semua jenjang pendidikan baik dari TK, SD, SMP, SMA, PT yaitu:

Pertama, hambatan pedagogis. Hambatan pedagogis merupakan hambatan yang dialami oleh tenaga pendidik/pengajar baik dari pendidik kurang menggunakan pembelajaran inovatif dan aktif agar siswa tidak jenuh, kebanyakan pendidik belum menguasai teknologi dan media padahal di pembelajaran era pandemi diwajibkan berbasis $e$-learning, pendidik juga merasa jenuh dan kelelahan mengajar melalui daring di depan gadget terus menerus. Seharusnya guru menjelaskan dengan berbagai media dan sejelas-jelasnya agar siswa dapat menerima materi dengan baik (Nurdin, 2021) (Ruktiari, Septiana, \& Piu, 2021).

Kedua, hambatan sarana dan prasarana. Hambatan sarana dan prasarana merupakan hambatan yang ditimbulkan karena kurangnya media yang dapat digunakan untuk menunjang pembelajaran yang efektif (Budiman, 2021). Hambatan yang sering muncul yaitu, susahnya akses intenet, boros kuota internet karena akses yang cukup lama, belum tersedianya akses wifi gratis di setiap desa, dan siswa masih banyak yang belum memiliki gadget untuk sarana belajar (Huzaimah \& Risma, 2021) (Khanan Auladi, Rahmaini, \& Rokhimawan, 2020).

Ketiga, hambatan internal siswa. Hambatan internal siswa merupakan hambatan yang terjadi karena rendahnya motivasi dan minat belajar siswa. Hal ini disebabkan karena siswa merasa jenuh terhadap metode pengajaran yang kurang interaktif dari guru (Hariyanti, Haq, \& Hidayat, 2020). Kebanyakan guru hanya mengganti pembelajaran dengan penugasan semata. Padahal seharusnya guru lebih berinovasi dengan metode dan media yang digunakan supaya interaktif, dan tetap menjelaskan materi seperti biasa. Akibatnya, siswa merasa jenuh serta menurunnya motivasi dan minat belajar. Kesiapan pembelajaran daring mempengaruhi hasil belajar belajar siswa (Paramita \& Subroto, 2021).

Keempat, hambatan lingkungan eksternal siswa. Hambatan tersebut berasal dari lingkungan interaksi siswa seperti, orang tua dan teman bermain siswa. Pada dasarnya, siswa membutuhkan dukungan untuk berprestasi dari orang tuanya (Kholisho \& Marfuatun, 2020). Hambatan belajar siswa terjadi karena orang tua siswa tidak terbiasa mendidik/mendampingi pembelajaran khususnya pada siswa jenjang TK dan SD. Kebanyakan siswa di usia tersebut belum memiliki kesadaran ataupun mampu mengoperasikan gadget untuk proses pembelajaran, sehingga peran pendampingan orang tua sangat signifikan. Pada kasus ini, orang tua siswa lebih sibuk dengan urusan kerja dan sudah kelelahan. Hambatan lainnya muncul dikarenakan teman bermain siswa yang juga mengalami hal serupa sehingga mereka bertemu hanya untuk bermain bukan buat belajar.

\section{PENUTUP}




\section{4

Berdasarkan hasil dari pembahasan di atas, maka dapat ditarik suatu kesimpulan tentang kegagalan dan hambatan pembelajaran di sekolah pada masa pandemi di Indonesia bahwa 95\% pembelajaran pada masa pandemi belum efektif serta terdapat hambatan-hambatan yang dialami seperti, hambatan pedagogis, hambatan sarana dan prasarana, hambatan internal siswa, dan hambatan lingkungan eksternal siswa. Saran untuk mengatasi hambatan-hambatan tersebut diperlukan sistem yang menyeluruh dari pemerintah menyiapkan sarana dan prasarana, kemudian untuk guru perlu diadakan pendampingan sebagai upaya meningkatkan pemahaman metode dan media yang digunakan dalam pembelajaran serta pendampingan orang tua untuk meningkatkan motivasi belajar siswa.

\section{DAFTAR PUSTAKA}

Afnibar, Fajhriani, D., \& Putra, A. (2020). ANALISIS KESULITAN BELAJAR MAHASISWA DALAM KULIAH ONLINE (Studi pada Mahasiswa Bimbingan Konseling Islam UIN Imam Bonjol Padang). Al Irsyad: Jurnal Bimbingan Konseling Islam, 11(2), 187-196. Retrieved from http://diasdiari.bl

Agustin, M., Puspita, R. D., Nurinten, D., \& Nafiqoh, H. (2020). Tipikal Kendala Guru PAUD dalam Mengajar pada Masa Pandemi Covid 19 dan Implikasinya. Jurnal Obsesi : Jurnal Pendidikan Anak Usia Dini, 5(1), 334. https://doi.org/10.31004/obsesi.v5i1.598

Bahar, S. (2020). Permasalahan-Permasalahan Sekolah Menengah Pertama (SMP) Bunda Dalam Pembelajaran Jarak Jauh Sebagai Dampak Pandemi Covid-19. Alasma: Jurnal Media Informasi Dan Komunikasi Ilmiah, 02(02), 217-230.

Budiman, J. (2021). Evaluasi Pelaksanaan Pembelajaran Daring Di Indonesia Selama Masa Pandemi Covid-19. VOX EDUKASI: Jurnal Ilmiah Ilmu Pendidikan, 12(1), 104-113. https://doi.org/10.31932/ve.v12i1.1074

Hariyanti, D., Haq, A., \& Hidayat, N. (2020). Pelaksanaan Pembelajaran Biologi Secara Daring Selama Pandemi Covid-19 di Kabupaten Jember. ALVEOLI: Jurnal Pendidikan Biologi, $1(1), 11-21$.

Huzaimah, P. Z., \& Risma, A. (2021). Hambatan yang Dialami Siswa Dalam Pembelajaran Daring Matematika Pada Masa Pandemi COVID-19. Jurnal Cendekia: Jurnal Pendidikan Matematika, 05(01), 533-541.

Kafi, M. B., Mahmudah, \& Muslimah. (2020). Problematika Pembelajaran Shalat pada Masa Pandemi Covid-19 di MIN 3 Kotawaringin Barat. Jurnal Al-Qiyam, 1(2), 1-10.

Kahfi, A. (2020). Tantangan Dan Harapan Pembelajaran Jarak Jauh Di Masa Pandemi Covid 19. Dirasah, 03(2), 137-154. Retrieved from https://stai-binamadani.e-journal.id/jurdir

Kemendikbud. (2020). SE Mendikbud: Pembelajaran Secara Daring dan Bekerja Dari Rumah Untuk Mencegah Penyebaran Covid-19. Jakarta. Retrieved from https://www.kemdikbud.go.id/main/blog/2020/03/se-mendikbud-pembelajaran-secaradaring-dan-bekerja-dari-rumah-untuk-mencegah-penyebaran-covid19

Khanan Auladi, Rahmaini, A., \& Rokhimawan, M. A. (2020). Kendala Guru Dalam Pembelajaran Tematik Jarak Jauh Selama Masa Pandemi Covid-19 Di Madrasah Ibtidaiyah Nurul Ummah (Minu) Kotagede Yogyakarta. As-Salam: Jurnal Studi Hukum Islam \& Pendidikan, 9(2), 163-188. https://doi.org/10.51226/assalam.v9i2.141

Kholisho, Y. N., \& Marfuatun, M. (2020). Daya Serap Pelaksanaan Mata Kuliah Kependidikan DiTengah Pandemi Covid-19. Edumatic : Jurnal Pendidikan Informatika, 4(1), 131-140. https://doi.org/10.29408/edumatic.v4i1.2155

Lubis, W. (2020). Analisis Efektivitas Belajar Pada Pembelajaran Jarak Jauh (Pjj) Di Masa Pandemi Covid-19. Jurnal Pendidikan Bahasa Dan Sastra Indonesia, 5(1), 139-140.

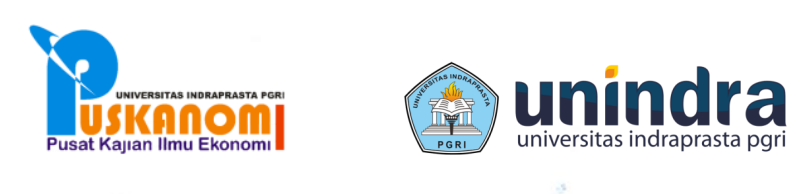


Nurdin. (2021). Kendala Pandemi Covid-19 Terhadap Proses Pembelajaran Online di MIN 4 Bungo 1. Jurnal Inovasi Pendidikan Dan Teknologi Informasi, 02, 122-130.

Nurkolis, N., \& Muhdi, M. (2020). Keefektivan Kebijakan E-Learning berbasis Sosial Media pada PAUD di Masa Pandemi Covid-19. Jurnal Obsesi : Jurnal Pendidikan Anak Usia Dini, 5(1), 212. https://doi.org/10.31004/obsesi.v5i1.535

Paramita, Y., \& Subroto, W. T. (2021). Faktor Kritis Kesiapan E-Learning Pendorong Perfoma Belajar Ekonomi Siswa SMA Selama Pandemi Covid-19. Jurnal Kependidikan: Jurnal Hsil Penelitian Dan Kajian Kepustakaan Di Bidang Pendidikan, Pengajaran Dan Pembelajaran, 7(2), 314-327.

Rahayu, A. suci, Amalia, A. R., \& Maula, L. H. (2020). Analisis Kesulitan Guru dalam Pembelajaran Daring di Masa Pandemi Covid-19 di Sekolah Dasar. Jurnal PGSD, 6(2), $1-6$.

Ramdhani, M. N., \& Wulandari, S. S. (2021). Analisis Efektivitas Kuliah Online pada Pembelajaran Kesekretarisan di Prodi Pendidikan Administrasi Perkantoran. Journal of Office Administration: Education and Practice, 1(1), 66-81.

Ruktiari, R., Septiana, A. I., \& Piu, S. W. (2021). Analisis Tingkat Kesiapan Pembelajaran Daring di Masa Pandemi COVID-19 Pada Guru SMK. Jurnal Instek: Informatika Sains Dan Teknologi, 6, 140-149.

Wahyuningsih, K. S. (2021). Problematika Pembelajaran Daring Di Masa Pandemi Covid-19 Di SMA Dharma Praja Denpasar. Jurnal Pangkaja, 24(1), 107-118.

Yudhistira, S., \& Murdiani, D. (2020). Pembelajaran Jarak Jauh: Kendala dalam Belajar dan Kelelahan Akademik. MAARIF Institute, 373-393.

Yupelmi, M. (2020). Pengaruh Pembelajaran Daring Terhadap Hasil Praktek Pewarnaan Rambut Di Kelas Xi Sekolah Menengah Kejuruan (Smk) Pada Masa Pandemi Covid-19. Jurnal Pendidikan Dan Keluarga, 12(2), 33-37. https://doi.org/10.24036/jpk/vol12iss02/832 